\title{
Characterization and Partial Purification of an Endothelial Cell Growth Factor from Human Platelets
}

George L. King and Sherry Buchwald

Research Division, Joslin Diabetes Center, and Department of Medicine, Brigham and Women's Hospital, Harvard Medical

School, Boston, Massachusetts 02115

bstract. Platelets have been shown to affect the growth of vascular endothelial cells. This report describes the characterization and partial purification from human platelets of a novel growth factor which can stimulate human endothelial cells to synthesize DNA and grow. Platelets were lysed by sonication and the particulate fraction removed by ultracentrifugation at $100,000 \mathrm{~g}$. The supernatant of the platelet lysate stimulated the incorporation of $\left[{ }^{3} \mathrm{H}\right]$ thymidine into DNA of endothelial cells by 20 -fold and caused a threefold increase of cell number in $2 \mathrm{~d}$ in culture. Gel filtration on Sephacryl S-200 and dialysis with exclusion membranes resulted in a 50-fold purification of this growth-promoting substance. Two peaks of endothelial-growth factor (ENDO-GF) were observed with apparent molecular weights of 65,000 and 135,000 . Further characterization showed that ENDOGF differed from platelet-derived growth factor since it was very heat labile and more potent in stimulating growth in endothelial cells than in fibroblasts. The isolation of an ENDO-GF from platelets suggests that platelets may have a role in the growth and healing processes of human endothelium.

\section{Introduction}

Platelets have been shown to affect the metabolism and the function of vascular endothelium (1-5). Apart from these wellrecognized interactions between platelets and endothelial cells, in areas such as thrombosis, hemostasis, and vascular permeability, some studies have suggested that factors from the platelets may also contribute to the preservation of capillary integrity (6-9). Gimbrone et al. showed that thyroid glands perfused with

Received for publication 7 July 1983 and in revised form 23 September 1983.

J. Clin. Invest.

(c) The American Society for Clinical Investigation, Inc.

0021-9738/84/02/0392/05 \$1.00

Volume 73, February 1984, 392-396 plasma lacking in platelets exhibited more breakdown of capillary endothelium than the same organ exposed to plasma supplemented with platelets (6). Earlier clinical observations noted a close association between thrombocytopenia and purpuric hemorrhages (9-11).

Growth factors have been clearly demonstrated in platelets. One of the best characterized is platelet-derived growth factor (PDGF), ${ }^{1}$ which can stimulate the growth of vascular smooth muscle cells and fibroblasts (12-14). However, PDGF has not been found to be biologically active in endothelial cells $(14,15)$. Several groups have demonstrated that whole platelets can actually stimulate the growth of endothelial cells (6-9), although others could not replicate this finding in platelet lysates $(16$, 17). In the present report, we have partially purified and characterized an endothelial growth factor (ENDO-GF) from human platelets that appear to be capable of stimulating DNA synthesis and cell growth in cultured human endothelial cells.

\section{Methods}

Purification procedures. Outdated human platelets were purchased from New England Blood Service (Boston, MA). The platelets were washed in phosphate-buffered saline (PBS) without $\mathrm{Ca}^{++}$and $\mathrm{Mg}^{++}$and centrifuged at $20,000 \mathrm{~g}$. All purification steps were carried out at $4^{\circ} \mathrm{C}$. The platelets were suspended in PBS at a concentration of $50 \mathrm{mg} / \mathrm{ml}$ of protein and lysed by ultrasonication for $1 \mathrm{~min}$ (sonifier cell distruptor 200; Branson Sonic Power Co., Danbury, CT). After sonication, the platelet lysate was ultracentrifuged (Beckman Instruments Inc., Fullerton, CA) at $100,000 \mathrm{~g}$ for $60 \mathrm{~min}$ and precipitate was discarded. The supernatant was dialyzed against PBS for $24 \mathrm{~h}$ using dialysis membrane (Fisher Scientific Co., Chicago, IL) with molecular weight exclusion of $10,000-14,000$, then fractionated through a Sephacryl S-200 column $(1.5 \times 80 \mathrm{~cm}$, Pharmacia Fine Chemicals Inc., Piscataway, NJ).

Culture of human endothelial cells. Primary human endothelial cells from umbilical veins were generously provided by Dr. M. Gimbrone, Jr. (Brigham and Women's Hospital), were serially passaged by the method of Maciag et al. using partially purified ENDO-GF from bovine hypothalamus, and grown on fibronectin-treated tissue culture dishes $(18,19)$. Umbilical cells were used up to 10 passages. The endothelial cells retained their morphological features as observed by inverted phase contrast microscopy. In addition, the cells were found to be positive for Factor VIII antigen using indirect immunofluorescence with antibody to human Factor VIII $(20,21)$.

1. Abbreviations used in this paper: ENDO-GF, endothelial growth factor, FBS, fetal bovine serum; PDGF, platelet-derived growth factor. 
$\left[{ }^{3} H\right]$ Thymidine incorporation into DNA. Cells were grown to near confluence at $37^{\circ} \mathrm{C}$ in six well plates (Costar, Cambridge, MA). The growth media of M199, containing $10 \%$ fetal bovine serum (FBS) and ENDO-GF from bovine hypothalamus, was replaced with M199 media containing $0.5 \%$ FBS and $2.5 \mathrm{mg} / \mathrm{ml}$ of bovine serum albumin at $\mathrm{pH}$ 7.4 for $24 \mathrm{~h}$. Indicated concentrations of growth factors or ENDO-GF were added for $14-18 \mathrm{~h}$ before the cells were pulsed with $\left[{ }^{3} \mathrm{H}\right]$ thymidine, $2 \mu \mathrm{Ci} / \mathrm{ml}$, for $30 \mathrm{~min}$ at $37^{\circ} \mathrm{C}$. The cells were solubilized with $0.1 \%$ sodium dodecyl sulfate and the DNA precipitated with $10 \%$ trichloroacetic acid at $4^{\circ} \mathrm{C}$ as described previously $(21-23)$.

Cell number determination. Cell number was determined using a hemocytometer and Coulter counter (Coulter Electronics Inc., Hialeah, FL). The cells were released from the dishes by trypsin-EDTA and diluted sufficiently to prevent significant aggregation. The cell preparations were then counted in triplicate.

Protein assays. Protein concentration was estimated by the method of Lowry et al. with bovine serum albumin as standard (24). Pure PDGF was a generous gift of Dr. C.-H. Heldin (University of Uppsala, Sweden). Plasma-derived fetal bovine serum and FBS were purchased from Sterile Systems Inc. (Logan, UT).

\section{Results}

Partial purification of ENDO-GF from human platelets. Outdated human platelets were lysed by sonication. The crude lysate was ultracentrifuged at $100,000 \mathrm{~g}$. The supernatant was then dialyzed
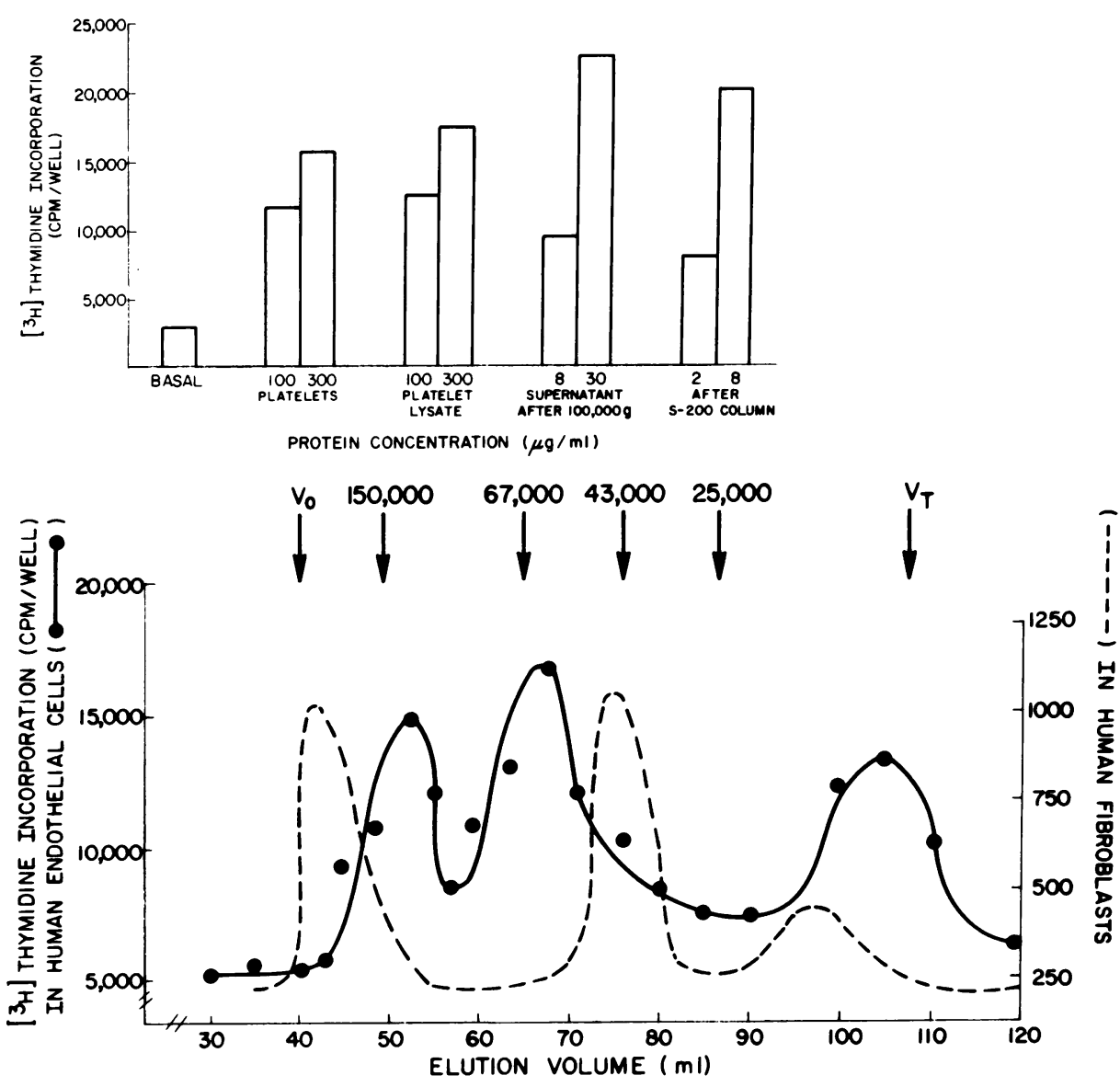

using membrane with molecular weight exclusion of 10,000 14,000 . Preparations from the various steps in the purification of ENDO-GF (see Methods) were assayed for their potency to stimulate $\left[{ }^{3} \mathrm{H}\right]$ thymidine incorporation into DNA of human umbilical vein endothelial cells as shown in Fig. 1 (top). Whole platelets and platelet lysate stimulated DNA synthesis equally well in a dose-dependent manner. The growth-promoting activity appears to be due to a large and soluble molecule, since it was found in the supernatant fraction after ultracentrifugation and was not dialyzable. Further purification was achieved using gel chromatography with Sephacryl S-200. Fractions eluted off the Sephacryl S-200 column were assayed for growth-promoting effects on both human fibroblasts and endothelial cells (Fig. 1, bottom). Three peaks of activity for growth effects in human endothelial cells were found corresponding with approximate molecular weight of $135,000,65,000$, and total volume of the column. When assayed in human fibroblasts, three different peaks of growth-promoting effects were observed in the areas of void volume, molecular weight of 40,000 , and the total volume. The peak at the approximate molecular weight of 40,000 was probably due to PDGF, which has a reported molecular weight of 30,000-36,000 $(13,14)$. Comparison of the protein concentrations of ENDO-GF required to stimulate $\left[{ }^{3} \mathrm{H}\right]$ thymidine incorporation with $100 \mathrm{mg} / \mathrm{ml}$ of whole platelet
Figure 1. Top: Stimulation of $\left[{ }^{3} \mathrm{H}\right]$ thymidine incorporation into human umbilical endothelial cells by ENDO-GF at each step of purification. The procedures for assay are described in the Methods section. Bottom: Stimulation of $\left[{ }^{3} \mathrm{H}\right]$ thymidine incorporation into human umbilical endothelial cells (๑) or human fibroblasts (- - ) by fractions eluted from a Sephacryl S-200 column. Human fibroblasts were derived from biopsy from forearm of adult volunteers as previously described and assayed as the endothelial cells $(22,23)$. 


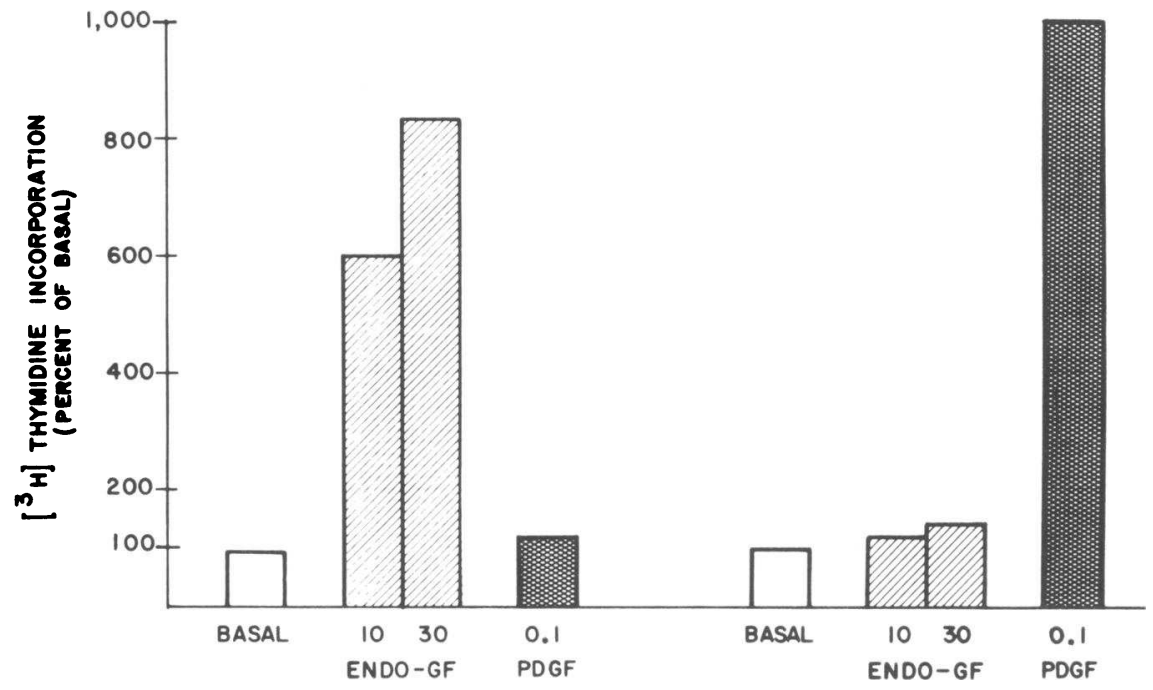

PROTEIN CONCENTRATION $(\mu \mathrm{g} / \mathrm{ml})$
Figure 2. A comparison of the specificity of the growth effect of ENDO-GF and PDGF on human umbilical vein endothelial cells (left) and human fibroblasts $($ right $)$. Partially purified ENDO-GF after the gel chromatography step and pure PDGF were used for these experiments. Procedures for the $\left[{ }^{3} \mathrm{H}\right]$ thymidine incorporation assay have been described previously (21-23). revealed that an approximate 50 -fold purification had been accomplished after gel chromatography.

Specificity of growth effect of ENDO-GF. Partially purified preparations of ENDO-GF from the S-200 column were assayed in both human fibroblasts and endothelial cells. At the same concentrations, ENDO-GF was very potent in stimulating DNA synthesis in human endothelial cells, but it was not very active in the fibroblasts. In contrast, pure PDGF was very potent for stimulation of DNA synthesis in the fibroblasts but ineffective in the endothelial cells (Fig. 2).

Effect of ENDO-GF on the growth of endothelial cells. Besides being able to stimulate DNA synthesis, ENDO-GF was also able to increase cell numbers, as shown in Fig. 3. FBS alone could increase endothelial cell growth by $30 \%$. However, the addition of either partially purified ENDO-GF or crude platelet lysate with $10 \%$ FBS stimulated cell growth by $>100 \%$ above the FBS alone.

The growth effects of ENDO-GF, alone and combined with various growth media, were studied. As shown in Table I, the purified crude platelet lysate could stimulate DNA synthesis and a cell number increase, whereas the Sephacryl columnpurified ENDO-GF stimulated only DNA synthesis. However, when ENDO-GF was added with either FBS or plasma-derived FBS, both DNA synthesis and cellular proliferation were stimulated by two to threefolds greater than serum or plasma alone. Note that, although plasma and serum stimulated $\left[{ }^{3} \mathrm{H}\right]$ thymidine incorporation after $16 \mathrm{~h}$ of preincubation to a lesser degree than ENDO-GF or platelet lysate, they were equally potent in increasing cellular proliferation.

Characterization of ENDO-GF. When ENDO-GF was incubated at various temperatures, its biological potency was diminished by $>50 \%$ at $37^{\circ} \mathrm{C}$ and lost almost all its effects when incubated at $57^{\circ}$ and $100^{\circ} \mathrm{C}$ for $30 \mathrm{~min}$ (Fig. 4).

In addition to being heat labile, ENDO-GF was also sensitive to the proteolytic action of trypsin. ENDO-GF was progressively inactivated by treatment with increasing concentrations of trypsin between 0.1 and $1 \%$. However, when trypsin inhibitor was added simultaneously with the trypsin, no inhibition of the growth-promoting action was observed. Similarly, no inhibition was observed if trypsin and ENDO-GF were incubated at $4^{\circ} \mathrm{C}$. These data strongly suggest that ENDO-GF from human platelets is a heat-labile protein or proteins.

\section{Discussion}

Platelets contain many bioactive agents that affect the metabolisms and functions of vascular endothelial cells (1-5). Some

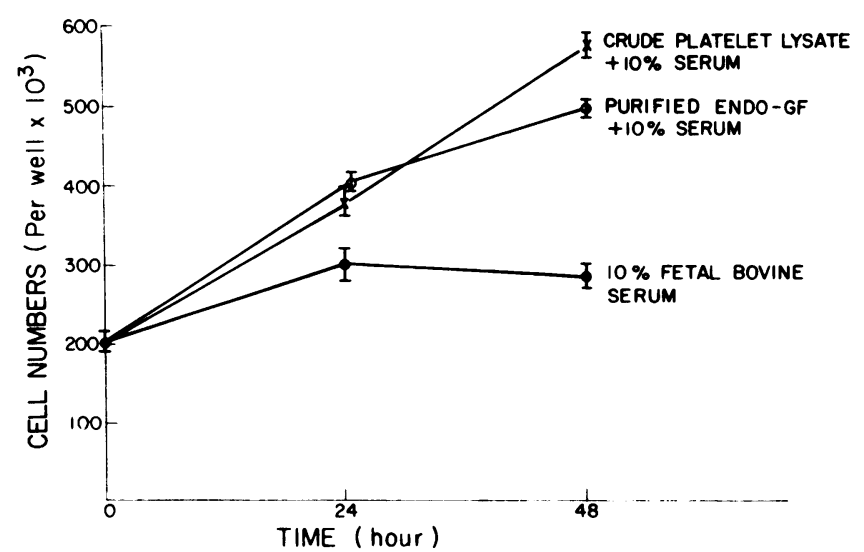

Figure 3. Comparison of the effect of FBS (๑), platelet extract (x), and partially purified ENDO-GF (O) on the growth of human umbilical vein endothelial cells. FBS (Sterile Systems Inc.) was heat inactivated at $56^{\circ} \mathrm{C}$ for $30 \mathrm{~min}$. The preparation of platelet lysate and ENDO-GF were described in Methods. 
Table I. Effect of ENDO-GF and Other Growth Media on the Proliferation of Endothelial Cells

\begin{tabular}{|c|c|c|}
\hline M199 media plus & $\begin{array}{l}\text { [3] Thymidine } \\
\text { incorporation* }\end{array}$ & $\begin{array}{l}\text { Cell no. } \pm \mathrm{SD} \ddagger \text { after } \\
3 \mathrm{~d} \text { incubation }\end{array}$ \\
\hline & $c p m / w e l l \pm S D$ & \\
\hline \multicolumn{3}{|l|}{$0.25 \%$ Bovine serum albumin } \\
\hline and $0.5 \%$ FBS & $3,162 \pm 332$ & $136,000 \pm 20,000$ \\
\hline Crude platelet lysate $(200 \mu \mathrm{g})$ & $27,857 \pm-$ & $304,000 \pm 68,000$ \\
\hline \multicolumn{3}{|l|}{ Partially purified ENDO-GF } \\
\hline$(5 \mu \mathrm{g})(10 \mu \mathrm{g})$ & $19,634 \pm 1,846$ & $-\S$ \\
\hline $5 \%$ FBS & $6,023 \pm 726$ & $336,000 \pm 56,000$ \\
\hline \multicolumn{3}{|l|}{$5 \%$ FBS and partially purified } \\
\hline ENDO-GF $(10 \mu \mathrm{g})$ & $23,074 \pm 2,981$ & $640,000 \pm 30,000$ \\
\hline 5\% Plasma-derived FBS & $5,349 \pm 649$ & $300,000 \pm 28,000$ \\
\hline \multicolumn{3}{|l|}{$\begin{array}{l}5 \% \text { Plasma-derived fetal } \\
\text { bovine and partially }\end{array}$} \\
\hline purified ENDO-GF & $19,577 \pm 1,719$ & $508,000 \pm 40,000$ \\
\hline
\end{tabular}

* The data are the mean of three experiments. The method for the thymidine incorporation is as described in the Methods section. ¥ The results are the mean of two experiments. Cells are counted by a hemocytometer.

§ Data are not available because endothelial cells detach from the plates in media with very low proteins after $24 \mathrm{~h}$.

studies have suggested that platelets can promote growth of endothelial cells (6-9). However, PDGF, the only well-characterized growth peptide from the platelet, has no demonstrable receptor or growth effect on endothelial cells $(14,15)$. The data in this report have clearly documented that platelets contain a protein or proteins that can promote DNA synthesis and endothelial cell growth. This ENDO-GF resides in the cytoplasm of the platelets. Elution profile from the Sephacryl column suggested that ENDO-GF has two peaks of activity with the ap- proximate molecular weights of 65,000 and 135,000 . These two peaks could be in the form of monomer and dimer or could represent two different proteins. A third peak of activity, which was eluted from the column at the region of total volume, was probably due to the small molecules that have been shown recently to affect the growth of endothelial cells (9).

Biochemical characterization using trypsin and heat demonstrated that ENDO-GF is a protein and very heat labile. This extreme heat lability is probably the reason that other investigators were unable to demonstrate an effect on endothelial cells using platelet lysates. Because ENDO-GF was ineffective in human fibroblasts, it appears to be biologically specific for endothelial cells, although other cells have to be screened.

It is interesting that the ENDO-GF could increase the growthpromoting effect of both plasma and serum, since serum should contain all the factors released from the platelets which are the source of ENDO-GF. The most likely explanation is that ENDOGF in the serum has been denatured due to its extreme lability, exhibited by its loss of biological activity when tested above $37^{\circ} \mathrm{C}$. Alternatively, the growth factor activity could have been lost from the serum during the clotting process, indicating a relationship between this growth factor and the clotting mechanism.

The biochemical and biological properties of ENDO-GF are very different from those of PDGF. PDGF is a much smaller protein at $30,000 \mathrm{~mol} w \mathrm{w}$. PDGF is not inactivated at $56^{\circ}$ or $100^{\circ} \mathrm{C}$ and biologically has the reverse spectrum of ENDO-GF, since it is very potent in fibroblasts and has no effect on endothelial cells. ENDO-GF activity, in contrast, is associated with larger 65,000 and 135,000 heat-labile proteins that can stimulate endothelial cell growth. The large molecular size of ENDO-GF is rather unusual among other endothelial growth factors (25-29). Maciag et al. have purified an ENDO-GF from bovine hypothalamus which is approximated to have molecular weights of 25,000 and 70,000; however, it is possible that ENDOGF, like the insulin-like growth factors, is associated with a

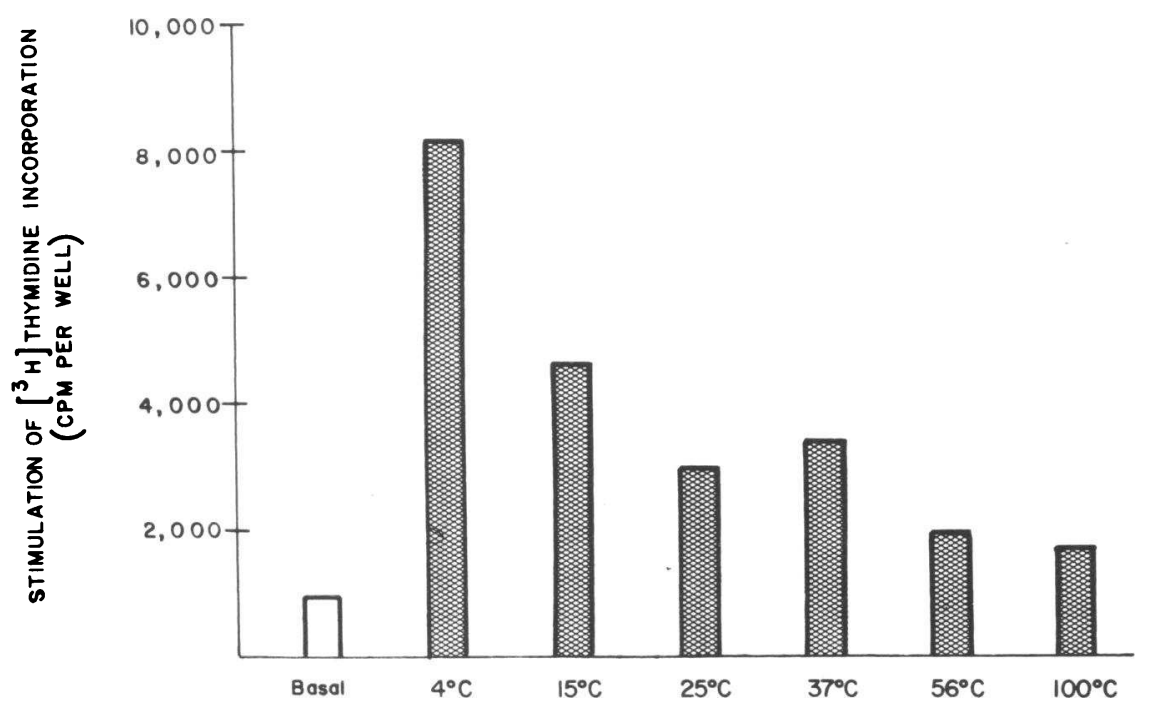

Figure 4. Effect of temperature on the growthpromoting effect of ENDO-GF. Partially purified ENDO-GF were incubated at the indicated temperature for $30 \mathrm{~min}$ and then rapidly cooled to $4^{\circ} \mathrm{C}$. The various samples were then assayed in human endothelial cells as described in Methods. ENDO-GF was preincubated for $30 \mathrm{~min}$ at the indicated temperature. 
binding protein that is responsible for the high molecular weight estimation $(30,31)$.

The demonstration of an ENDO-GF from human platelets suggests that platelets may have a growth-promoting role in vascular endothelial cells, perhaps at the process of endothelial cell regeneration, which is a crucial step in the healing of endothelial cell injury. Further work is in progress for the complete purification and characterization of ENDO-GF from human platelets.

\section{Acknowledgments}

The authors wish to thank Drs. C. Ronald Kahn and Michael A. Gimbrone, Jr. for the helpful discussions during the preparation of the manuscript. In addition, the secretarial assistance of Ms. Patti Morrison is gratefully acknowledged.

This work was done in part with the support of The American Heart Association. Dr. King is supported by a Career and Development Award from the American Diabetes Association.

\section{References}

1. Weksler, B. B., C. W. Ley, and E. A. Jaffe. 1978. Stimulation of endothelial cell prostacyclin production by thrombin, trypsin, and the ionophore A23187. J. Clin. Invest. 62:923-930.

2. Gimbrone, M. A., Jr., and R. W. Alexander. 1975. Angiotension II stimulation of prostaglandin production in cultured human vascular endothelium. Science (Wash. DC). 189:219-220.

3. Nachman, R. L., B. Weksler, and B. Ferris. 1972. Characterization of human platelet vascular permeability-enhancing activity. J. Clin. Invest. 51:549-556.

4. Handin, R. I., K. Curwen, and M. A. Gimbrone. 1981. The interaction of platelets with cultured cells. Ann. NY Acad. Sci. 3:42-50.

5. Zetter, B. R., L. K. Johnson, M. A. Shulman, and D. Gospodarowicz. 1978. The isolation of vascular endothelial cell lines with altered cell surface and platelet binding properties. Cell. 14:501-509.

6. Gimbrone, M. A., A. H. Richard, R. S. Cotran, J. Corkery, J. H. Handl, and J. Folkman. 1969. Preservation of vascular integrity in organ perfused in vitro with a platelet-rich medium. Nature (Lond.). 222:3336.

7. Saba, S. R., and R. G. Mason. 1975. Effects of platelets and certain platelet components on growth of cultured human endothelial cells. Thromb. Res. 7:807-812.

8. D'Amore, P., and D. Shepro. 1977. Stimulation of growth and calcium influx in cultured, bovine, aortic endothelial cells by platelets and vasoactive substances. J. Cell. Physiol. 92:177-184.

9. Clemmons, D. R., W. G. Isley, and W. T. Brown. 1983. Dialyzable factor in human serum of platelet origin stimulates endothelial cell replication and growth. Proc. Natl. Acad. Sci. USA. 80:1641-1645.

10. Gaydos, L. A., E. J. Freireich, and N. Mantel. 1962. The quantitative relation between platelet count and hemorrhage in patients with acute leukemia. N. Engl. J. Med. 266:905-909.

11. Friedman, R. J., M. B. Stemerman, B. Wenz, S. Moore, J. Gauldie, M. Gent, M. L. Tiell, and T. H. Spaet. 1977. The effect of thrombocytopenia on experimental arteriosclerotic lesion formation in rabbits, smooth muscle cell proliferation and re-endothelialization. $J$. Clin. Invest. 60:1191-1201.

12. Ross, R., J. Glomset, B. Kariya, and L. Harker. 1974. A plateletdependent serum factor that stimulates the proliferation of arterial smooth muscle cells in vitro. Proc. Natl. Acad. Sci. USA. 71:1207-1210.
13. Antoniades, H. N., C. D. Scher, and C. D. Stiles. 1979. Purification of human platelet-derived growth factor. Proc. Natl. Acad. Sci. USA. 76:1809-1813.

14. Heldin, C.-H., B. Westermark, and A. Wosteson. 1979. Plateletderived growth factor: purification and partial characterization. Proc. Natl. Acad. Sci. USA. 76:3722-3726.

15. Bowen-Pope, D. F., and R. Ross. 1982. Platelet-derived growth factor. II. Specific binding to culture cells. J. Biol. Chem. 257:51615171.

16. Wojick, J. D., D. C. Van Horn, A. J. Webber, and S. A. Johnson. 1969. Mechanism whereby platelets support the endothelium. Transfusion. 9:324-335.

17. Thorgeirsson, G., and A. L. Robertson, Jr. 1978. Platelet factors and the human vascular wall. Atherosclerosis. 30:67-78.

18. Gimbrone, M. A., Jr., R. S. Cotran, and J. Folkman. 1974. Human vascular endothelial cells in culture. Growth and DNA synthesis. J. Cell Biol. 60:673-684.

19. Maciag, T. G., G. A. Hoover, M. B. Stemerman, and R. Weinstein. 1981. Serial propagation of human endothelial cells in vitro. J. Cell Biol. 91:420-426.

20. Buzney, S. M., and S. J. Massicotti. 1979. Retinal vessel; proliferation of endothelium in vitro. Invest. Ophthalmol. Visual Sci. 18:1191-1195.

21. King, G. L., S. M. Buzney, C. R. Kahn, N. Hetu, S. Buchwald, S. G. Macdonald, and L. I. Rand. 1983. Differential responsiveness to insulin of endothelial and support cells from micro- and macro-vessels. J. Clin. Invest. 71:974-979.

22. King, G. L., C. R. Kahn, M. M. Rechler, and S. P. Nissley. 1980. Direct demonstration of separate receptors for growth and metabolic activities of insulin and multiplication-stimulating activity (an insulin-like growth factor) using antibodies to the insulin receptor. $J$. Clin. Invest. 66:130-140.

23. Rechler, M. M., J. M. Podskalny, I. D. Goldfine, and C. A. Wells. 1974. DNA synthesis in human fibroblasts: stimulation by insulin and by non-suppressible insulin-like activity (NSILA-S). J. Clin. Endocrinol. Metab. 39:512-521.

24. Freychet, P., C. R. Kahn, J. Roth, and D. M. Neville, Jr. 1972. Insulin interactions with liver membranes: independence of binding of the hormone and its degradation. J. Biol. Chem. 247:3953-3961.

25. Palverini, P. J., R. S. Cotran, M. A. Gimbrone, Jr., and E. R. Unanece. 1977. Activated macrophages induce vascular proliferation. Nature (Lond.). 269:804-806.

26. Chen, C. H., and S. C. Chen. 1980. Angiogenic activity of vitreous and retinal extract. Invest. Ophthalmol. Visual Sci. 19:596-602.

27. Folkman, J. 1982. Angiogenesis: initiation and control. In Endothelium. A. P. Fishman, editor. New York Acad. Sci., New York. 212-227.

28. D'Amore, P. A., B. M. Glaser, S. K. Brunson, and A. H. Fesselau. 1981. Angiogenic activity from bovine retina: partial purification and characterization. Proc. Natl. Acad. Sci. USA. 78:3068-3072.

29. Castellat, J. J., Jr., M. J. Karnovsky, and B. M. Spiegelman. 1980. A potent stimulation of vascular endothelial cell growth by differentiated 3T3-adipocytes. J. Cell. Biol. 87(2, Pt. 2):59a. (Abstr.)

30. Maciag, T., G. A. Hoover, and R. Weinstein. 1982. High and low molecular weight forms of endothelial cell growth factor. J. Biol. Chem. 217:5333-5336.

31. Moses, A. C., S. P. Nissely, I. J. Passamani, R. M. White, and M. M. Rechler. 1979. Further characterization of growth hormonedependent somatomedin binding-protein in rat serum and description of somatomedin binding-protein produced by rat liver cells in culture. Endocrinology. 104:536-546. 